\title{
CONNECTING THE VANISHING FLORA, FAUNA AND ITS RELATION TO THE INDIAN REMOVAL POLICY AS SEEN IN COOPER'S THE LEATHERSTOCKING TALES
}

\author{
Ceisy Nita Wuntu \\ c_wuntu@yahoo.com \\ English Department, Faculty of Languages and Arts, \\ Manado State University, Indonesia
}

\begin{abstract}
This study aims at connecting the vanishing flora, fauna and its Relation to the Indian removal policy in Cooper's The Leatherstocking Tales. This research applies an American Studies' interdisciplinary principle supplemented by the myth and symbol theory proposed by Henry Nash Smith. Smith claimed the importance of imaginative works in revealing American culture. He declared that the historical, anthropological and cultural, sociological, and ecological data as covered in this research can be equipped by data from imaginative works. Hence, in this research, those data are presented integratedly in their context of past and present. In this research, in order to highlight environmental matters in Cooper's The Leatherstocking Tales, the analysis covers the data above that are integrated with the data revealed in The Leatherstocking Tales as a whole by employing the concept of ecocriticism. The spirit of the immigrants to have a better life in the new world, stimulated by its rich, lush and beautiful circumstances, in fact, is not an aim of a sustainable life. The desire to improve their life is not enough without using and treating its environment wisely as well as facing it with the environmental conservation paradigm. The spirit of doing the exploitation is a consequence of western humanism value. The reason of coming to America to avoid the population density as well as the competition of life cannot be attained when the immigrants experience the same population density and harsh competition as in their old world and when the beautiful nature disappears, the forests become cities, the tranquility becomes noisy and crowded, and the people experience the uncomfortable life that many kinds of conflict can follow. It is not on the right path when they cannot
\end{abstract}


maintain the grandeur of nature, because they are not directing their way to the right, sustainable way of life as alerted and meant by Cooper. Ecologically, the superabundance of the land when it was encountered by the European immigrants had been a factor that had made the American people arrogant with the environment. The damage of the environment that is understood anthropologically, culturally, sociologically and ecologically was not an individual mistake. It was the responsibility of the government to provide law enforcement but unfortunately the government got involved in the violation of human rights and of the activities of exploiting natural resources. To Cooper, as seen in his work, the spirit of exploiting life and the environment can be overcome by the moral of ecological awareness. It is a hierarchy that starts from love or compassion, then appreciation, respect, wisdom, and justice and this hierarchy should be assisted by law. Cooper's ecological moral awareness arose as a protest against American progress. The immigrants' progress to Cooper is an extermination of human, flora, and fauna.

Key words: vanishing flora, fauna and Indians, James Fenimore Cooper, The Leatherstocking Tales, Cooper's ecological hierarchy

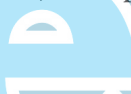

Abstrak: Kajian ini bertujuan untuk mengungkap hubungan menghilangnya flora, fauna dan orang-orang Indian dengan kebijakan penggusuran orang-orang Indian Penelitian ini mengaplikasikan prinsip antar disiplin yang dilengkapi dengan teori mitos dan symbol dari Henry Nash Smith. Smith menyatakan bahwa karya-karya imajinatif dapat mengungkap budaya Amerika, sehingga dapat digunakan untuk menjelaskan data sejarah, antropologi dan budaya, sosiologi dan data ekologi demikian pula sebaliknya dimana data-data dari berbagai bidang tersebut dapat juga digunakan untuk menjelaskan karya-karya imajinatif. Karena itu, data-data dari bidang-bidang tersebut bersama dengan datadata imajinatif dapat berintegrasi dalam konteks masa lalu dan kekinian menjelaskan persoalan lingkungan dalam The Leatherstocking Tales dengan menggunakan perspektif ekologi. Keinginan para imigran untuk memperoleh hidup yang lebih baik di dunia baru, telah distimulasi oleh kekayaan, kesuburan, dan keindahannya dan bukan untuk suatu kehidupan yang berkelanjutan. Adalah tidak cukup bagi para imigran untuk melakukan tindakan-tindakan bijaksana untuk menjaga kelestarian lingkungan. Semangat eksploitasi adalah konsekuensi dari nilai humanisme barat. Alasan untuk menghindari kepadatan penduduk serta kompetisi hidup tidak akan dapat terwujud ketika mereka kembali 
menjumpai pengalaman yang sama ketika keindahan alam hilang, hutanhutan menjadi kota, ketenangan menjadi kegaduhan, serta konflik-konflik yang menyertainya. Mereka berada di jalan yang salah seperti yang diperingatkan Cooper ketika mereka mengabaikan keagungan alam. Secara ekologi, kelimpahan yang merka jumpai di dunia baru, juga telah memicu mereka untuk berlaku tidak bijaksana terhadap alam. Kerusakan lingkungan yang dipahami secara antropologi dan budaya, secara sosiologi, dan secara ekologi bukan merupakan kesalahan individu. Adalah tanggung jawab dari pemerintah untuk menyediakan perangkat hokum untuk menjaganya, tetapi saying pemerintah juga terlibat dengan pelanggaran hak asasi dan kegiatan-kegiatan eksploitasi sumber daya alam. Bagi Cooper, semangat merusak lingkungan dapat diatasi dengan moral kesadaran lingkungan yang merupakan suatu hirarki yang dimulai dengan cinta, penghargaan, rasa hormat, kebijaksanaan atau kerifan, dan keadilan. Hirarki ini harus didampingi oleh hukum. Kesadaran moral ekologi Cooper merupakan protes terhadap kemajuan Amerika. Bagi Cooper, kemajuan tersebut merupakan penghancuran manusia, flora dan fauna.

Kata kunci: Tumbuh-tumbuhan, hewan, dan orang-orang Indian yang menghilang, James Fenimore Cooper, The Leatherstocking Tales, tahapan sikap ekologi Cooper

\section{INTRODUCTION}

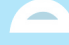

Environmental issues are often overlooked although the global environmental issue, namely global warming, is exacerbating natural phenomena. The recent natural disasters have been the results of environmental imbalance. Environmental conservation should be pursued to avoid the certain destruction of the Earth. According to Meijer \& Berg, the "Environmental protection is successful when the relevant root cause of the problem is removed or alleviated" (2010, p. 351). The environment imbalance is triggering the destructive floods, landslides, erosion and storm that often occurred everywhere in Indonesia, as well as 'Hurricane Sandy' that also occurred in the East coast of America including New York at the end of 2012. These disasters had been exacerbated by global warming (Barrert, 2012) Human actions and human activities that can damage the environment become a serious problem that requires awareness of the effects and dangers they cause. In an attempt to raise public awareness of the importance of treating the environment with care, ecological ideas in literature integrated with the society's perspective on the environment need to be revealed. Here, 
Glotfelty \& Fromm comment that "An ecologically focused criticism is a worthy enterprise primarily because it directs our attention to matters about which we need to be thinking. Consciousness raising is, its most important task. For how can we solve environmental problems unless we start thinking about them?" (1996, p. xxiv)

A literary work which has affective nature is a significant power to touch the deepest sense that can produce perfect consciousness as it successfully carries out its mission as a form generator of human consciousness. American Studies is a discipline which regards literary works not merely as fictions but also as intellectual documentations which can complement historical, cultural anthropology, ecological, and sociological data, as well as the data for various other fields. In this research, the writer uses The Leatherstocking Tales as a viewpoint in understanding the vanishing flora, fauna and the Indians from James Fenimore Cooper's time in the United States. The piece written by Cooper contains ideas that are aimed at the activities and actions of the destruction as well as the views or the way of maintaining the sustainability of life. The understanding of the views or ideas about life sustainability contained in this work is in the whole unity of the elements of the work; the author, the world, and ecosphere. Through this understanding, The Leatherstocking Tales can be clearly seen that it is not only regarded as a work of fiction but also contains the value of truth which is discovered through the experience of Cooper as the writer of The Leatherstocking Tales itself. His experience was obtained from intellectual and personality odysseys years before he wrote the story. The formation process on Cooper's view and thought towards the destruction and his ideal view in The Leatherstocking Tales shows the situation and the view of environment in America in Cooper's time.

The next idea is that The Leatherstocking Tales, which was written a long time ago between 1823-1841 will always be relevant for indefinite period of time is seen in this way for human will always be responsible for his own life. In realizing this, human will always be dependent on the natural environment. Moreover, the nature of human life as well as the nature of the environment which are universal has made the ideas in Cooper's work as the guardian for the sustainability of life. Ecocriticism theory that emerged in the late of 1970s used this work as a significant object of the study when the ecocriticism emerged in America at that time did not document Cooper's work as a work that contained environmental criticism which was beneficial to save life and humans. Therefore, this study is important to promote The Leatherstocking Tales 
as a work that deserves attention so that it can always be a reference for the ever evolving human civilization in sustainable life.

In Cooper's time, stories about people and their environment were often found in many kinds of writings, which at that time were called literary works. These works comprised travelogues, diaries, sermons, and letters. America's land that is rich, fertile, and beautiful when it was found by Christopher Columbus in $15^{\text {th }}$ century has resulted in a variety of dreams, ideals, and hopes that were found in these works. For this reason, 'myth and symbol school' has put the works in a strong position and counts them as important documents. Even though until today, Cooper's idea in his masterwork of The Leatherstocking Tales is not used as a reference or an important document by the United States of America to support the attempts to decrease gases causing greenhouse effect. Cooper's ecology concept which accompanies his view on America needs to be revealed to put him as a monumental American environment writer so that his work will always be used as a reference, especially in addressing today's crisis of global environment. As an objective, this research aims at revealing the connecting vanishing flora, fauna and vanishing Indians and its Relation to the Indian Removal Policy in Cooper's The Leatherstocking Tales.

\section{THEORETICAL FRAMEWORK}

A work in the field of American Studies is a collective work of several people from different disciplines who accommodate imaginative works as supplementary data. Historical, cultural, social, and anthropological data can be completed with the data from literary or imaginative works and vice versa, so, the data of literary or imaginative works can be completed with historical, cultural, social, and anthropological data (Smith, 1980, p. 14). The concept mentioned above is derived from the 'myth and symbol' school as proposed by Smith. Imaginative works by this school is considered to have essential elements that contribute to the formation of culture. The element is called as the inner element of image builders that produces images which has a place in consciousness. These images construct mental entities which then exist as collective representations. Mental construction can be understood through attitudes, process, and activities which can be observed. Myths and symbol, according to Nash Smith, describes smaller or bigger units of an object which build an intellectual construction that merges into the concept of an 'image'. The most prominent phenomenon in The Leatherstocking Tales is the 
phenomenon of environmental destruction which reflects American culture. The multi-disciplinary concept proposed by Smith (1980, p. 14) opens a room for this study to accommodate the discussion on the environment as seen in the work of Cooper. Since the environmental destruction issue is dominant in this work, the writer brings this issueof ecocriticism as a literary criticism which examines the relationship of literature and the environment, as the main focus of discussion. The criticism explores how literary works view the concept of the world as a place for life. The principle of this criticism then changes the concept of 'world' or the world in literature into a larger concept, which is called 'ecosphere'. Its coverage consists of "text, writer, and the ecosphere" (Glotfelty \& Fromm, 1996, pp. xviii-xix). Rueckert says that all environment elements have the right to be protected by law so that the vision of ecology should be complemented by a legal instrument (cited in Glotfely \& Fromm, 1996, p. 108).

With regards to Cooper, the environment destruction in his time needs to be confirmed through historical events that happened in the past to give a basis for the multidisciplinary analysis in anthropology, culture and sociology. Sociological basis is employed to reveal the strong driving factors that the community causes inherent environmental destruction. Historical approach from Collingwood argues that history is "thought about the past" (Dray, 1995, p. 16), anthropological approach states that genetic changes can be caused with radiation factors, extreme temperature, and chemical changes (Crawford, 2007 p. 171). Meanwhile, cultural approach, according to Hoenigman, is an approach which is related to the manifestation of culture, such as ideas, activities, and artifacts (Sampurna, 2013, p. 237).

Social approach is applied to understand the events related to the environment in America starting from the era of exploration to the period of construction in America of Cooper's time. Ideas and activities which go along through the understanding of social reality that exists in community through an understanding that "reality is socially constructed" are applied to analyze the problems of the environment (Berger \& Luckmann, 1966, p. 13). This approach is then employed to identify the truth which is obtained through the internalization process of how the immigrants as well as the native Americans determine their attitude and action. 


\section{METHOD OF STUDY}

The method applied in this study is a grounded theory of generating theory. The process to obtain the theory is done inductively, in which the acquisition of theory is done through collected data and not through testing theories (Glaser \& Strauss, 1995, pp. 2-4). The main factors of grounded method are the data collection and analysis. These two steps are related to each other since analysis already starts during the process of data collection. The principle of application is the data conceptualization activity obtained after encoding the data or labelling activity by doing a comparison and logical questioning. Coding is seen as the main activity to generate a theory. Coding consists of three stages, namely encoding based on the nature, encoding to make the linking between categories, and encoding to simplify the varied data until arriving at the core category. The next step is redefining main problems and eventually re-testing to reach the generated theory. The data used in this paper are qualitative data but the study also accommodates supporting data which are related to numbers and statistical data by taking account the principle of American Studies and the myth and symbol theoretical approaches. From these two theoretical approaches, the writer can conduct a comprehensive study to obtain the intellectual constructions that are derived from the collaboration of various fields that comprise the past and present the concept and emotions in the 'image' portrayed by Cooper.

The fields involved in this study are history, culture and anthropology, sociology and ecology that are presented as a whole. The data used are categorized based on these fields to accommodate the data from the imaginative works. In principle, the data collected are based on the problems of study associated with the phenomenon under study. As an initial step, although this method does not start from a theory, an understanding of the concepts and phenomena are required as initial asset which is called as a 'determination of context and phenomenon' to determine topics. From the topics, problems of the study can be formulated as a guideline in collecting the data.

As for the object of this research, the work of The Leatherstocking Tales written by James Fennimore Cooper was chosen. The formal object is the environmental destruction in America during Cooper's time. The data collected is based on the problems of the study even though the problems themselves are still general. The main discussion is actually to identify forms of environmental damage as seen in The Leatherstocking Tales as a starting point 
for the study of environmental destruction from a historical, cultural, anthropological, sociological, and ecological perspective. The discussion is then linked to ecological vision that is understood through the work acquired through the application of ecocriticism theory which also became reference of an ideal environment that can maintain sustainable living. The data is then collected as much as possible and then continued with encoding that starts with the naming or labelling the data with certain concepts. In this stage, there are a few labels from the collected data that is the destruction of flora and fauna as seen in The Leatherstocking Tales. The cause of the activities of environmental destruction was perpetrated by European settlers and this can be figured out through the historical, anthropological, cultural, sociological and ecological perspectives. Treatments for the elements of environment covered by this study are then linked to the environmental destruction in the perspectives of history, anthropology, culture, sociology, ecology, and the concept of environmental conservation to arrive at the last stage which determines the core category which then returns to the process of the problems of the study to sharpen the more specific problem and a fitting test is done among the categories, problems of study, and the data. The conformity of these three elements produces a core category as a theory that is considered strong.

\section{RESULT}

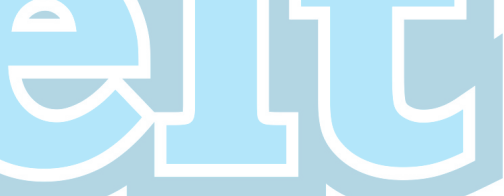

\section{A. James Fenimore Cooper and the Environmental Ideas of The Leatherstocking Tales}

The Leatherstocking Tales has made Cooper known as one of the founders of American literary identity. To be a great writer, Cooper was supported by his intellectual ability even though formally he did not complete his higher education. It can be proven through his ability to overcome personal and family problems, as well as the problem of facilities limitations that could have hampered him from being a good writer. It can also be seen in his ability to overcome competition in his career as a writer and his ability to digest the problems faced by American authors in their attempt to confirm the identity of the material as well as the form of American literature. Moreover, he managed to choose the right materials for the issues faced by then ascent state. He could also give an early warning to the Americans to do great things that turned out to have significant effect on solving global environmental problems today. These works contain Cooper's views about the environment in America 
as well as his ideas about environmental preservation that will always be significant. One example is about his concern on the environment, and sustainable life on earth is that his hero's warning to Judge Temple "Put an ind, Judge, to your clearings...Use, but don't waste” (p. 250). Another example of Natty Bumppo's feeling of envy to the flora destruction is reflected in this quotation:

"... I never visited the towns; but often have heard the place you speak of named."'T is a wide clearing there, I reckon."”Too wide! Too wide! They scourge the very 'arth with their axes. Such hills and hunting grounds as I have seen stripped of the gifts of the Lord, without remorse or shame! I tarried till the mouths of my hounds were deafened by the blows of chopper, and then I came west in search of quiet. It was a grievous journey that I made, a grievous toil to pass through falling timber, and to breathe the thick air of smoky clearings, week after week, as I did. 'T is a far country too that State of York, from this!" (The Prairie, p. 674).

For Natty Bumppo, it is a shame to destruct hills and hunting grounds as the place for flora, fauna and human beings to live. Cooper also has mentioned in this quotation about pollution when he mentions "to breathe the thick air of smoky clearings, week after week, as I did.". He had reminded the pollution issue long before the issue arises.

Being raised in a family that embraced Quaker Christianity enabled Cooper to have a deep sense of empathy towards all of God's creations comprising men and the flora and fauna and it can be seen clearly in his work, The Leatherstocking Tales. The feeling of closeness to tranquility and peace reflected from the tranquility and shade of the forest he got from childhood until his teenage years when he lived with his family in a frontier area surrounded by forests also contributed to the emergence of the ideas in the work. Forest loss due to the forest clearing for residential areas as well as the loss of the Mohican tribe who used to live in the area around his house has triggered the feeling of hatred against the forest clearing activity done by the pioneers. Cooper himself had experienced unfair treatments from the government where he lived. They uncompromisingly set their authority over the land of his family. Cooper had significant capabilities as a competent writer. He succeeded in empowering varieties of elements comprehensively such as American problems as well as his problems, opportunities in which he is at the right time to remind American people early to give their attention on 
their environment, needs of all people, and his potency either cognitively or affectively and in psychomotor through his success in presenting his works The Leatherstocking Tales that is well-known and admired not only in America but almost throughout the entirety of Europe.

\section{B. The vanishing flora, fauna and the Indians as seen in The Leatherstocking Tales}

Currently, the data show that approximately 635 species have disappeared from the plains of North America and hundreds more species were endangered within the interval of the 1800 s to the 2000s. The species are classified into three categories: (a) the flora and fauna which have become extinct, (b) the flora and fauna that are thought to have become extinct, and (c) the flora and fauna which have become extinct in the wild, but still exist in preservations, such as national parks, botanical gardens, etc. In the span of two centuries - between the 1800 s and 1900s - there had been a significant number of extinctions of the flora and fauna in the United States. In the 1800 s the total species of flora and fauna according to Stein, Bruce, Kutner, Lynn, Adams, \& Jonathan (2000) were considered extinct was 73 species whereas in 1900s the total species of flora and fauna which have become extinct or are deemed to be extinct reached the number of 557 species. Cooper's fears were confirmed when Martha, a local name for the last bird of the species of Passenger Pigeon, died at Cincinatti Zoo, Ohio, on September 1st 1914 (Stein, Bruce, Kutner, Lynn, Adams, \& Jonathan, 2000, p. 49). Cooper's cry about the vanishing of the birds happened long before the vanishing of the pigeons in 1914. In the novel, Natty says "I wouldn't touch one of the harmless things that kiver the ground here, looking up with their eyes on me, as if they only wanted tongues to say their thoughts" (Cooper, 1985, p. 250).

There has been no sighting of this species to this day, thus it is considered extinct. This was the species of bird that Cooper selected for his work, The Pioneers, one of the works in The Leatherstocking Tales. It was used as the object of pleasure for the people from Templeton village, by killing them in mass number and leaving them to rot. The US government has also supported a wave of immigrants heading west with programs such as Homestead Act in 1862, The Timber Culture Act in 1873 "to make western lands more appealing", and Desert Land Act (Petulla, 1988, pp. 177-178). So too was made through the Pacific Railway Act by loaning money and providing a vast land for the Union Pacific Railroad Company and Central Pacific Railroad 
Company to build the Transcontinental Railroad, and to not enforce any tax to the industrial players which resulted in the continuous growth of their industrial companies (Petulla, 1988, p. 175). The policies set by the government had given a sad influence for the Indians who inhabited the lands. "Land was very much an article of white Americans bargained over especially after the Revolution ... (it) offered the greatest promise of financial gain" (Petulla, 1988, p. 64). The Native Americans were not treated humanely. It had been proven with the existence of the "Indian Removal policy" to facilitate the need to exploit the gold in the regions of Georgia. Prior to the enactment of the policy in 1830, Cooper's masterpiece The Last of the Mohicans emerged, precisely in 1826. Thousands of victims as the result of the eviction were known as the 'Trail of Tears' or in the language of the Cherokees "Nunna Dual Tsuny". In "The Last of The Mohicans" Cooper writes about Chingakhook's grief when his son, the last of the Mohicans dies "I am a 'blazed pine, in a clearing of the pale-faces.' My race has gone from the shores of the salt lake and the hills of the Delaware. But who can say that the sepent of his tribe has forgotten his wisdom! I am alone-..." have I live to see that last warrior of the wise race of the Mohicans!" (p. 878)

When the first immigrants succeeded in turning the wilderness into urban areas and exterminated the natives, as experienced by the Mohican tribe in New York and Cherokees Tribe in the "Trail of Tears", it can be said that the spirit of success which was based on the spirit of capitalism was not an absolute savior. If humans could coexist in harmony, and could maintain a good balance with their environment such as with the flora and fauna, as well as all the elements of the Earth, then God would not bring any disaster upon the Earth.

However, in reality, the government in Cooper's era was involved in the destruction. At the current moment, the government's attention toward environmental safety is overlooked and instead, focused on the economic sectors. On September 24th 2014, in New York, many marches were organized in an effort to arouse the determinants of the environmental policy on safety issues to be discussed in the UN conference in the city. The marches were conducted by the environmental activists, one of which was Al Gore who is an environmentalist fighting against global warming. These could be interpreted as a warning aimed at the US as well as the world in general. In reality, in materializing their dreams to acquire a good life, liberty, and happiness, they took the path that led to destruction. The prosperity and peace offered by the 
New World of America were only temporary and it could jeopardize the harmony of life as feared by Cooper.

Cooper's s protagonist, Natty Bumppo, harbored a deep hatred towards environmentally damaging activities such as the destructions of flora and fauna as well as the unfair and inhumane treatments towards the Indians. The activities that show the immigrant's greediness can be understood from this quotation:

"It seems to me, if there's a plenty of anything in this mountainous country, it's the trees. If there's any sin in chopping them, I've a pretty heavy account to settle; for I have chopped over the best half of a thousand acres, with my own hands, counting both Varmount and York states; and I hope to live to finish the hull, before I lay up my axe. Chopping comes quite natural to me, and I wish no other employment..." (Cooper, 1985, p. 229)

Natty's friendship with Chingachgook, who belonged to the Mohican tribe, which was part of the Delaware tribe, showed that they shared the same principles. It was made clear that Natty was raised among the Delaware tribe, a tribe famous for its wisdom. Honoring the Cooper Award to the young chief of the Pawnee tribe represented the Old Trapper or Natty's admiration toward the young Pawnee tribe chief in The Prairie. Nevertheless, Natty seemed conflicted in justifying the act of killing as punishment, as what the chief of the Pawnee tribe was going to carry out, even though it was in retaliation of what his enemies had done. According to the Old Trapper, it was against the virtues she had believed in. Evidently, Cooper had met the head of the Pawnee tribe he admired and he sensed the presence of such trait which he described as 'savage heroism'. This explained that in The Leatherstocking Tales Cooper was not in favor of the Indians, he only defended their commendable nature and attitude. Similarly, he did not hate the white men either. However, he refused to disregard the values of righteousness such as the sense of responsibility toward themselves as well as their surrounding environment such as in The Leatherstocking Tales,.Cooper's hero, Natty Bumppo really admires Chingakghook and the whole of his tribe, the Delaware Mohicans in "The Last of The Mohicans" (1826) as well as the Pawnees in "The Prairie" (1827) that belong to the good Indian stock, and he does not like the Hurons and the Sioux that belong to the bad stock (Cooper, 1985). 
The belief that all of the elements of the Earth were interrelated and would last forever was believed by the Indians and Chingachgook, who was highly respected and admired by Natty Bumppo. She believed that he could prevent his people from destructing the environments. In living her life, Natty Bumppo with her Christianity teachings centered on love for others, was no different from Chingakhook's Indian. There were rituals performed to compensate the animals they had killed for food. The Indians understood that these animals had the right to live and be protected (Hughes, 1983, p. 50). They often compared these animals with human beings, which in return would make it hard for them to kill the animals even if it had been for food. The Christian teachings to love our fellow human beings and our surroundings were implemented by both Natty Bumppo and the Indians. The attitudes, behaviors, and actions of Natty Bumppo, which were based on the Christian teachings of love, led to her passion for flora and fauna and her strong feeling against hurting others as written in the Bible "love your peers as you would yourself" (Matthew, pp. 22-39). The Indians also believed in treating the surrounding environments with the utmost care, which derived from their deep sense of empathy for the lives of the living beings.

Compassion is a form of love. This sense of love, as commanded by God, had dissuaded Natty from brutal actions that damaged the environment. She felt that the living environment should be protected accordingly because here is where love actually came from. Compassion is the manifestation of God's mandate of love, and the manifestation of love as life's mandate is to save others and the environment. This is the basis of the other forms of environmental preservation such as appreciation, respect, wisdom, and justice. These are Cooper's ecological hierarchy in The Leatherstocking Tales.

C. Connecting the vanishing flora, fauna and the vanishing Indians and its Relation to the Indian removal policy

Changes that occur in the wilderness of America were a result of human destructive activities. These changes were the essence of Cooper's biggest concern and protest towards European settlers. He was troubled because these settlers had had a higher civilization, measured from the knowledge and the technology they possessed, compared with the American Indian. The existence of America today made possible by European settlers cannot be separated from the Enlightenment that happened in the $11^{\text {th }}$ century when Europe underwent the Dark Age in the $5^{\text {th }}$ century. The later years influenced and opened up the ideas which had confined them in political, economic and religious crises. The 
wealth of the Eastern world brought by the 'crusaders' had lured Europeans to acquire wealth of the Eastern. Through this step, the period of exploration emerged and created some areas considered to be new and rich that could be colonized, one of which was American that was initially discovered by Columbus (Barck \& Lefler, 1959, p. 2). Along with the exploration period and the opening lines between Eastern and Western world, occurred the 'revolution of taste' that thrived on the activity of observations and experiments leading to the development of science and technology that gave birth to Western humanism which led to the superiority of Europe over the developing countries (Hoffer, 2006, pp. 42-44) The attitude of superiority was not received well by the natives. In addition, according to the law governing European settlers, coming to a new land and taking over the property of others could not be justified. The opposition from the Indians was a resulting fight for their rights. Therefore, the idea of western humanism which they believe to be able to shift the rights of the indigenous people was also experienced by settlers from Africa, China and Japan.

The tempting properties, wealth and abundance undermined the ideal view of religious communities at the time. An example is the decision made by John Wintrop, a priest, for his community. He decided to separate from another religious community led by Thomas Hook and live in a coastal area with a better economic prospect. Likewise, Thomas Hook and his followers moved from an area they initially agreed for their residential area. They move to a larger area for the sake of convenience and ownership (Rohrer, 1957, pp. 15-21). These changes displayed by religious settlers reflected the strong desire of the immigrants that could adversely give impacts on the nature and human resources. Therefore, the desire for conquest became a dominant atmosphere. How religious figures such as John Wintrop and Thomas Hook and their followers were affected cannot be separated from the influence of the super abundance in America. America's large land has diverted Thomas Hook and his followers from their initial mission, which was to spread their religion.

The spirit towards the industry and technology advancements as promoted by Benjamin Franklin when he was faced with America's abundance had been forwarded by Walt Whitman in his poem I Hear America Singing. Melodious songs in the work of Whitman showed his appreciation for what America had achieved in various fields (http://www.poets.org/poetsorg/ poem/i-hear-america-singing). Appreciation toward human achievements was more clearly visible in Whitman's Passage to India. He explicitly stated his admiration for the development of telecommunications and railroads 
(Whitman, http://www.Cliffsnotes. com/literature/l/leaves-of-grass/summaryand-analysis-Calamus/passage-to-india) Whitman's appreciation for the work and achievements of American people represents the price of hard work and suffering which had been experienced by the settlers in conquering 'American Wilderness'.

The decision to leave the 'Old World' or the old state was not an early joy for the European immigrants to be where they wanted to be. On the way to their destination as experienced by John Smith and his friends, they had to face harsh storms and some of them became ill. Their hopes to arrive safely and well at their destination had not yet been acquired when they had several times passed islands in hardships. Another difficulty was when they had to deal with hostile indigenous people. In that place they had to deal with the views of vile deeds. The murder carried out by Native Americans was a serious terror especially for those who were sick and starving when they did not have a place to stay in the 'wilderness' and they still had to work hard (Baym, 1989, pp. 1113). When they worked hard they should have been provided with food that met the standard for nutrition. In reality, they were getting weaker and sicker because they only ate biscuits every day. Sometimes they did not eat anything. 1624 was a time of famine for them. This incident was recorded by Captain John Smith in The General History of Virginia. The number of immigrants decreased drastically from 500 s of people to no more than the 60 people. The remaining immigrants were portrayed in a devastating picture. The period of famine and the difficult times had resulted in cannibalism, where humans prey on each other for food.

The harsh environmental factor received little attention. The reality faced by immigrants in America was in contrast to what they had believed to be the New Canaan with the promise of prosperity. One of the many hardships experienced by the first settlers in the New World was when the winter came they were not equipped with the proper equipment. They were not prepared for the different condition as what they were used to in Europe. They were not equipped with enough medical equipment and medicine. They did not have enough places to take shelter from the storms. They had shortage of food supplies, and numerous psychological sufferings caused by the hardships they encountered. Another difficulty they faced was the fear of facing the Indians with their traditional fighting equipment such as arrows and axes. These conditions were far from what they had hoped for by moving to America. 
The success of the immigrants to clear land from the West to California in 1809 did not come easily. It was achieved through many physical and mental hardships and sufferings, even deaths. The clearings were conducted for more than two hundred years, from the year 1607 to 1809. During this period, they had managed to adapt well to the present circumstances and conditions, which were different from where they came from in England. The keys in conquering the harsh American land were strong will, high spirit, courage and hard work. The rigors of life in the middle of the wilderness had been conquered at last, despite the number of casualties. A new life in the New World was successfully pioneered. The American wilderness is a determining factor in the country's success in various fields (Turner, 1920, pp. 3-4). Frederick Jackson Turner stated that the stimulation of the American wilderness has spawned the American spirit, the spirit of success, the new Americans regardless of where they were originally from. The American wilderness has brought forth the characteristics, traits, habits, and new cultures which are authentically American. The persistence for hard work which was the trait of American character had generated a great price for these European settlers, which were primarily from the UK. The difficult experiences at the beginning of America had formed a spirit based on the 'myth of innocence' or the feeling of being free from sin and moral guilt (Adi, 2003, p. 129)

This myth was the power, the strength of which has been proven by the remarkable achievements of today. So too was the belief of the confidence gained from the success of the unyielding and hardworking attitude. America as a developed country can be seen from its achievements in various aspects of life. These proved the validity of the beliefs they keep.

It is understood that the aspects that determined the success of America were, first, the opportunity. The prospective settlers of the New World had the opportunity to learn about the prosperity stored in the East, an opportunity to escape from the suffering they faced in the dark period in the fifth century Europe, the opportunity that came when Christopher Columbus discovered the American continent, the opportunity when there were challenges on the way from Europe to America across the ruthless ocean, and the opportunity to face the American wilderness. The second was the will to maintain a life which generated goodwill, determination, strong courage, and hard work. The third was the confidence that generated beliefs of the existing cultures at the time they were conquering and opening the American wilderness as a place to develop the civilization for more than 200 years, from the arrival of the first settlers on the of North American soil in 1607 in Virginia, and eventually 
stopped in California in 1809. The spirit which has developed was the spirit of capitalism, the spirit to gather as many crops without any consideration toward the enslaved groups which were displaced and treated unfairly.

The act of destruction was not considered an individual error when the European settlers had to fight for their life. The social circumstances in Europe starting from the Dark Age which has caused their desire to make the journey to the East has opened their mind to build a culture community that emphasized reason and progress. It was supported by the abundance of natural resources that allowed them to take actions that damaged the environment as it is shown by Kirby, the wood Chopper in "The Pioneer" (1823) (Cooper, 1985). These violations were the government's responsibility, but it turned out that even the government was also engaged in such activities as Indian removal policy and the government policies to stimulate people moving west.

\section{CONCLUSION}

The vanishing flora, fauna and the Indians feared by Cooper in his time emerged as a consequence of the cultural, social and ecological condition in the United States.; Culturally, the condition arises from the values of western humanism that are derived from reason and rational value, socially, the immigrants' hardship experience, and ecologically, the superabundance in the new world. Cooper gave high appreciations to the rights of living creatures, and to life itself through love or 'compassion', and thus appreciation, respect, wisdom, and justice would follow. These appreciations arose from the universal moral values which were also enshrined in Cooper's Christian belief and the spiritual beliefs of the Native Americans, the Indians. Cooper firmly addressed this through a work called Deerslayer (1841) that those destructive actions must be addressed by law made by man. The laws should always accompany government's policies concerning the environment, and the enforced policies must be obtained through politics. All the while the government's responsibility in addressing those destructive acts was involved in the tragic events that befell the Indians, and the government's extravagant behavior affected their policies.

Cooper acknowledged that the source of human life came from nature. Cooper was not completely against the killing of animals and tree loggings when he said "... use but do not waste" (Cooper, 1985) which he wrote in his novel section, The Pioneers (1823) A real life is the life that takes into account 
the environment. A life without any consideration toward the environments will perish. 'The center position' of his every stance emerged from his spiritual beliefs. Every characteristic of nature he understood showed his wisdom in facing the dilemma between progress and environmental preservation. The ecological principles over his wisdom had shaped a hierarchy that started with compassion, respect, wisdom, and justice that offered the solution to address life issues or 'life awareness' currently faced by the United States and the world in general. These issues of the advancement of science and technology, followed by the capitalistic society without any environmental awareness, which could lead to dehumanization and destruction, are basically what Cooper was against.

\section{REFERENCES}

Adi, I. R. (2003). Reconciling the American Myth of Innocence with Popular Consciousness: A Study On American Action Films of 1990s. An unpublished dissertation. Yogyakarta: Gadjah Mada University.

Barck \& Lefler. (1959). Colonial America. New York: The Macmillan Company.

Barry, Pr. (2002). Beginning Theory: An Introduction to Literary and Cultural Theory. UK: Manchester University Press.

Baym, N., et al. eds. (1989). The Norton Anthology of American Literature, $3^{\text {rd }}$ ed., Vol. 1. New York: W.W. Norton \& Co.

Baym, N., et al. eds. (2003). Cherokee Memorials. The Norton Anthology of American Literature. $6^{\text {th }}$ ed, Vol. B. New York: W.W. Norton \& Company, pp. 1029-1039.

Berger, P.L. \& Luckmann T. (1966). The Social Construction of Reality. England: Penguin Group.

Bloomberg. (2012 November 5-11). It's Global Warming, Stupid. Businessweek. USA.

Bradford, W. (1989). Plymouth Plantation. In Baym, N., Gottesmasn, R., Holland, L.B., Kalston, D., Murphy, F., Parker, H., Prichard, W.H., Wallace, P.B. (Eds). The Norton Anthology of American Literature. New York: W.W. Norton \&Co. 
Burdick, N. S. (1981). The evolution of environmental consciousness in nineteenth-century America: An interdisciplinary study. An unpublished dissertation.

Calloway, C. G., (2012). First Peoples. New York: Bedford/ St. Martin's.

Cooper, J.F. (1985). The Pioneer, The Last of the Mohicans, and The Prairie. The Leatherstocking Tales, Vol. I. USA: The Library of America.

Cooper, J.F. (1985). The Deerslayer and The Pathfinder. The Leatherstocking Tales, Vol. II. USA: The Library of America.

Cooper, J.F. (1979). Introduction. The Last of the Mohicans. New York: Dodd, Mead \& Co.

Cooper, J. F. (1838). The American Democrat or Hints on the Social and Civic Relations of the United States of America. New York: H. \& E. Phinney.

Dodd, Elizabeth. (2014). Ecocriticism: Literary studies in an age of environmental crisis. Natural Resources and Environmental Sciences Seminar Series. USA: Kansas State University, Ackert.

Franklin, W. (2007). James Fenimore Cooper: The Early Years. USA: Yale University Press.

Garrard, G. (1998). Ecocriticism. London and New York: Routledge Press.

Glaser, B. G., \& Strauss, A. L. (1967). The Discovery of Grounded Theory: Strategies for Qualitative Research. USA: A Division of Transaction Publisher.

Glotfelty, C., Fromm, H., eds. (1996). The Ecocriticism Reader Landmarks in Literary Ecology. Georgia: University of Georgia Press.

http://www.bbc.co.uk/religion/religions/christianity/subdivisions/quakers1. html.

http://www.poets.org/poetsorg/poem/i-hear-america-singing.

http://www.cliffsnotes.com/literature/l/leaves-of-grass/summary-and-analysiscalamus/passage-to-india).

Hoffer, P. C. (2006). The Brave New World: A History of Early America. Maryland: The John Hopkins University Press.

Hughes, J. D. (1983). American Indian Ecology. USA: Texas Western Press, El Paso. 
116 Celt, Volume 15, Number 2, December 2015, pp. 97-117

Jackson, A. (1838, June 12). On Indian removal policy. Message to Congress. National Archives and Record Administration. Records of the United States Senate, 1789-1990. Record Group 46.

Jahoda, G. (1976). The Trail of Tears. Great Bitain: George Allen \& Unwin Publisher, Ltd.

Kammen, M. (1980). People of Paradox: an Inquiry Concerning the Origins of American Civilization. USA: Oxford University Press.

Lounsbery, T. (1886). James Fenimore Cooper. New York: Houghton, Mifllin and Co.

Meijer, J., \& Berg, D. A. (2010). Handbook of Environmental Policy: Environmental Science, Engineering and Technology. New York: Nova Science Publishers, Inc.

National Center for Public Policy Research. (1997, July 25). Text of the ByrdHagel Resolution. Retrieved November 2, 2006 from http:/www. nationalcenter.org/Kyoto Senate.html

Petulla, J. M. (1988). American Environmental History. Ohio: Merrill Publishing Co. and A Bell \& Howell Co.

Porter, T. (2008). And Grandma Said... Iroquois Teachings: As Passed Through the Oral Tradition. USA: Xlibris Corporation.

Slotkin, R. (1986). The Fatal Environment: The Myth of the Frontier in the Age of Industrialization, 1800-1890. Connection: Wesleyan University Press.

Spiller, R.E., Throp, W., Johnson, T.H., Canby, H.S, Ludwig, R.M., Gibson, \& W.M. (Eds.) (1974). Literary History of the United States. New York: Macmillan Publishing Co., Inc.

Spiller, R. E. (1965). James Fenimore Cooper. New York: McGraw-Hill Book Co.

Stein, B., Kutner, L. S., Adams, J. S., (2000). Precious Heritage: The Status of Biodiversity in the United States. New York: Oxford University Press.

Tate, C. (1973). The Search for a Method in American Studies. Minneapolis: University of Minnesota Press.

Turner, F. J. (1920). The Frontier in American History. New York: The Arizona Board of Regents. 
Wuntu, C. N. Connecting the Vanishing Flora, Fauna and its Relation to the

United Nations Commission of Experts' Final Report (S/1994/674), Section III. B. Retrieved January 10, 2006 from http://www.ess.uwe. ac.uk/comexpert/III-IV_D.htm\#III.B.

Whitman, W. 1900. A Passage to India. http://www.bartleby.com/ 142/183.html.

Winthrop, J. (1630). A Model of Christian Charity. Retrieved January 10, 2006 from http://www.john-uebersax.com.

Zhao, X. \& Park, E. J. (2013). Asian Americans: An Encyclopaedia of Social, Cultural, Economic and Political History (3 Volumes). Santa Barbara: ABCCLIO.

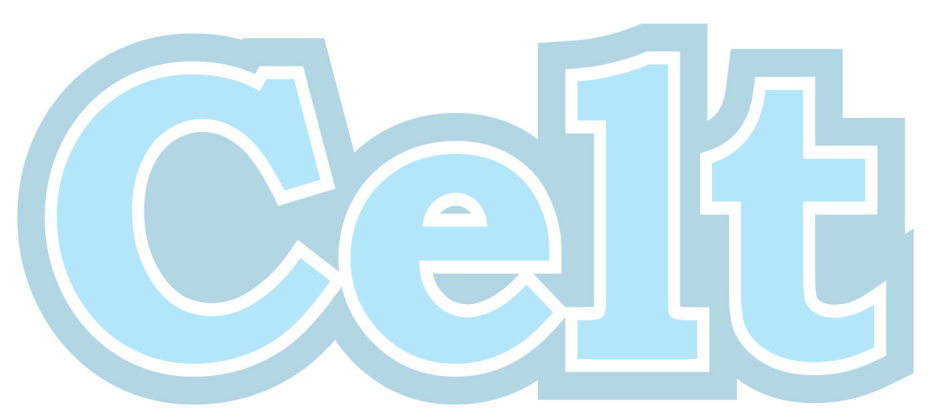

